\title{
6. References
}

1. Barkley RA, Guevremont DC, Anastopoulos AD, DuPaul GJ, Shelton TL. Driving-related risks and outcomes of attention deficit hyperactivity disorder in adolescents and young adults: a 3- to 5-year follow-up survey. Pediatrics 1993; 92: 212-218.

2. Barkley RA, Murphy KR, Kwasnik D. Motor vehicle driving competencies and risks in teens and young adults with attention deficit hyperactivity disorder. Pediatrics 1996; 98 : 1089-1095.

3. DiScala C, Lescohier I, Barthel M, Li G. Injuries to children with attention deficit hyperactivity disorder. Pediatrics 1998; 102: 1415-1421.

4. Babinski LM, Hartsough CS, Lambert NM. Childhood conduct problems, hyperactivityimpulsivity, and inattention as predictors of adult criminal activity. J Child Psychol Psychiatry 1999; 40: 347-355.

5. Biederman J, Wilens T, Mick E, Spencer T, Faraone SV. Pharmacotherapy of attentiondeficit-hyperactivity disorder reduces risk for substance use disorder. Pediatrics 1999; 104(2). www.pediatrics.org/cgi/content/full/104/2/e20.

6. Chilcoat, HD, Breslau N. Pathways from ADHD to early drug use. J Am Acad Child Adolesc Psychiatry 1999; 38: 1347-1354.

7. Weiss G, Hechtman L, Milroy T, Perlman, T. Psychiatric status of hyperactives as adults: a controlled prospective 15-year follow-up of 63 hyperactive children. J Am Acad Child Adolesc Psychiatry 1985; 24: 211-230.

8. Manuzza S, Klein RG, Bessler A, Malloe P, LaPadula M. Adult psychiatric status of hyperactive boys grown up. Am J Psychiatry 1998: 155: 493-498.

9. American Psychiatric Association. Diagnostic and Statistical Manual of Mental Disorders, 4th edition (DSM-IV). Washington, DC: American Psychiatric Association, 1994.

10. World Health Organization. The International Classification of Diseases, 10th revision. Geneva: World Health Organization, 1992.

11. National Health and Medical Research Council. Attention Deficit Hyperactivity Disorder. Canberra: Commonwealth Department of Health and Family Services; 1997.

12. Cantwell DP. Attention deficit disorder: a review of the past 10 years. J Am Acad Child Adolesc Psychiatry 1996; 35: 978-987.

13. Barkley RA. Attention-deficit hyperactivity disorder. Sci Am 1998 Sept.

14. Swanson JM, Sergeant JA, Taylor E, Sonuga-Barke EJS, Jensen PS, Cantwell DP. Attention-deficit hyperactivity disorder and hyperkinetic disorder. Lancet 1998; 351(9100): 429-433.

15. Levy F, Hay DA, McStephen M, Wood C, Waldman I. Attention-deficit hyperactivity disorder: a category or a continuum? Genetic analysis of a large-scale twin study. J Am Acad Child Adolesc Psychiatry 1997; 36: 737-744.

16. Epstein JN, Conners CK, Erhardt D, Arnold LE, Hechtman L, Hinshaw SP, Hoza B, Newcorn JH, Swanson JM, Vitiello B. Familial aggregation of ADHD characteristics. $J$ Abnorm Child Psychol 2000; 28: 585-594.

17. Faraone SV, Biederman J, Mick E, Williamson S, Wilens T, Spencer T, Weber W, Jetton J, Kraus I, Pert J, Zallen B. Family study of girls with attention deficit hyperactivity disorder. Am J Psychiatry 2000; 157: 1077-1083.

18. Biederman J, Faraone SV, Keenan K, Knee D, Tsuang MT. Family-genetic and psychosocial risk factors in DSM-III: attention deficit disorder. J Am Acad Child Adolesc Psychiatry 1990; 29: 526-533.

19. Biederman J, Faraone SV, Keenan K, Benjamin J, Krifcher B, Moore C, SprichBuckminster S, Ugaglia K, Jellinek MS, Steingard R, Spencer T, Norman D, Kolodny R, Kraus I, Perrin J, Keller MB, Tsuang MT. Further evidence for family-genetic risk factors in attention deficit hyperactivity disorder: patterns of comorbidity in probands and relatives in psychiatrically and pediatrically referred samples. Arch Gen Psychiatry 1992; 
49: 728-738.

20. Biederman J, Faraone SV, Mick E, Spencer T, Wilens T, Kiely K, Guite J, Ablon JS, Reed E, Warburton R. High risk for attention deficit hyperactivity disorder among children of parents with childhood onset of the disorder: a pilot study. Am J Psychiatry 1995; 152: 431-435.

21. Thapar A, Holmes J, Poulton K, Harrington R. Genetic basis of attention deficit and hyperactivity. Br J Psychiatry 1999; 174: 105-111.

22. Leung PWL, Luk SL, Ho TP, Taylor E, Mak FL, Bacon-Shone J. The diagnosis and prevalence of hyperactivity in Chinese schoolboys. Br J Psychiatry 1996; 168: 486496.

23. Rohde LA, Biederman J, Busnello EA, Zimmermann H, Schmitz M, Martins S, Tramontina S. ADHD in a school sample of Brazilian adolescents: a study of prevalence, comorbid conditions, and impairments. J Am Acad Child Adolesc Psychiatry 1999; 38: 716-722.

24. Goldman LS, Genel M, Bezman RJ, Slanetz PJ. Diagnosis and treatment of attentiondeficit-hyperactivity disorder in children and adolescents. JAMA 1998; 279: 11001107.

25. Glow RA. A validation of Conners TQ and a cross-cultural comparison of prevalence of hyperactivity in children. Advances in Human Psychopharmacology. Burrows G and Werry J (editors). Connecticut: JAI Press, 1980.

26. Sawyer MG, Arney FM, Baghurst PA, Clark JJ, Graetz BW, Kosky RJ, Nurcombe B, Patton GC, Prior MR, Raphael B, Rey J, Whaites LC, Zubrick SR. Mental Health of Young People in Australia. Canberra: Commonwealth Department of Health and Aged Care, 2000.

27. Lavigne JV, Gibbons RD, Christoffel KK, Arend R, Rosenbaum D, Binns H, Dawson N, Sobel H, Isaacs C. Prevalence rates and correlates of psychiatric disorders among preschool children. J Am Acad Child Adolesc Psychiatry 1996; 35: 204-214.

28. Quinn P, Nadeau K. Understanding preschool girls with ADHD. Attention! ${ }^{\circledR}$ Magazine 2000; 6(5): 42.

29. Gaub M, Carlson CL. Gender differences in ADHD: a meta-analysis and critical review. J Am Acad Child Adolesc Psychiatry 1997; 36: 1036-1045.

30. Jensen PS, Martin D, Cantwell DP. Comorbidity in ADHD: implications for research, practice, and DSM-V. J Am Acad Child Adolesc Psychiatry 1997; 36: 1065-1079.

31. Spencer T, Biederman J, Wilens T, Harding M, O’Donnell D, Griffin S. Pharmacotherapy of attention-deficit hyperactivity disorder across the life cycle. J Am Acad Child Adolesc Psychiatry 1996; 35: 409-432.

32. Pelham WE, Wheeler T, Chronis A. Empirically supported psychosocial treatments for attention deficit hyperactivity disorder. J Clin Child Psychol 1998; 27: 190-205.

33. Hazell P. Attention deficit hyperactivity disorder in preschool aged children. Clinical Approaches to Early Intervention in Child and Adolescent Mental Health-Volume 1. Kosky R, O'Hanlon A, Davis C (series editors). Adelaide: Australian Early Intervention Network for Mental Health in Young People, 2000.

34. Sonuga-Barke EJS, Daley D, Thompson M, Laver-Bradbury C, Weeks A. Parent-based therapies for preschool attention-deficit/hyperactivity disorder: a randomized, controlled trial with a community sample. J Am Acad Child Adolesc Psychiatry 2001; 40: 402 408.

35. Vitiello B, Severe JB, Greenhill LL, Arnold LE, Abikoff HB, Bukstein OG, Elliott GR, Hechtman L, Jensen PS, Hinshaw SP, March JS, Newcorn JH, Swanson JM, Cantwell DP. Methylphenidate dosage for children with ADHD over time under controlled conditions: lessons from the MTA. J Am Acad Child Adolesc Psychiatry 2001; 40: 188-196.

36. Hinshaw S. Psychosocial intervention for AD/HD: how well does it work? Attention! ${ }^{\circledR}$ Magazine 2000; 6(4): 30.

37. Bochner F, Allardice J, Ames D, Condon J, Johnson GF, Keks N, Mant A, McEncroe J, McGrath J, Mitchell P, Robinson J, Sawyer M, Tiller JWG, White J. Therapeutic Guidelines: Psychotropic_-Version 4. North Melbourne: Therapeutic Guidelines Limited; 
2000.

38. Connor DF, Fletcher KE, Swanson JM. A meta-analysis of clonidine for symptoms of attention-deficit hyperactivity disorder. J Am Acad Child Adolesc Psychiatry 1999; 38: 1551-1559.

39. Hazell P, Stuart, J. An RCT of clonidine augmentation of psychostimulants for ADHD and comorbid conduct problems: a mid-term report. ADHD in the Third Millennium: Perspectives for Australia, Conference Proceedings, March 16-18 2001.

40. Prince JB, Wilens TE, Biederman J, Spencer T, Wozniak JR. Clonidine for sleep disturbances associated with attention-deficit hyperactivity disorder: a systematic chart review of 62 cases. J Am Acad Child Adolesc Psychiatry 1996; 35: 599-605.

41. Wilens TE, Spencer TJ. Combining methylphenidate and clonidine: a clinically sound medication option. J Am Acad Child Adolesc Psychiatry 1999; 38: 614-616.

42. Swanson JM, Connor DF, Cantwell D. Combining methylphenidate and clonidine: illadvised. J Am Acad Child Adolesc Psychiatry 1999; 38: 617-619.

43. Pliska SR, Greenhill LL, Crismon ML, Sedillo A, Carlson C, Conners CK, McCracken JT, Swanson JM, Hughes CW, Llana ME, Lopez M, Toprac MG, The Texas Consensus Conference Panel On Medication Treatment of Childhood Attention-Deficit/Hyperactivity Disorder. The Texas children's medication algorithm project: report of the Texas Consensus Conference Panel on medication treatment of childhood attention-deficit/hyperactivity disorder-Part 1. J Am Acad Child Adolesc Psychiatry 2000; 39: 908-919.

44. Diller LH. Just say yes to ritalin! MSNBC news online. http//:msnbc.com 27 Febraury 2001.

45. Byrne JM, Bawden HN, DeWolfe NA, Beattie TL, Clinical assessment of psychopharmacological treatment of preschoolers with ADHD. J Clin Exp Neuropsychol 1998; 20: 613-627.

46. Ghuman JK, Ginsburg GS, Subramaniam G, Ghuman HS, Kau ASM, Riddle MA. Psychostimulants in preschool children with attention-deficit/hyperactivity disorder: clinical evidence from a developmental disorders institution. J Am Acad Child Adolesc Psychiatry 2001; 40: 516-524.

47. Rapoport JL, Buchsbaum MS, Zahn TP, Weingartner H, Ludlow C, Mikkelsen EJ. Dextroamphetamine: cognitive and behavioral effects in normal prepubertal boys. Science 1978; 199(4328): 560-563.

48. Rapoport JL, Buchsbaum MS, Weingartner H, Zahn TP, Ludlow C, Mikkelsen EJ. Dextroamphetamine. Its cognitive and behavioral effects in normal and hyperactive boys and normal men. Arch Gen Psychiatry 1980; 37: 933-943.

49. Elia J, Ambrosini PJ, Rapoport JL. Drug therapy: treatment of attention-deficit-hyperactivity disorder. N Engl J Med 1999; 340: 780-788.

50. Efron D, Jarman F, Barker M. Methylphenidate versus dexamphetamine in children with attention deficit hyperactivity disorder: a double-blind, crossover trial. Pediatrics 1997; 100(6). www.pediatrics.org/cgi/content/full/100/6/e7.

51. Barkley RA. Attention-Deficit Hyperactivity Disorder: A Handbook for Diagnosis and Treatment. New York: The Guilford Press, 1990.

52. Gillberg C, Melander H, von Knorring A, Janols L, Thernlund G, Hagglof B, EidevallWallin L, Gustafsson P, Kopp S. Long-term stimulant treatment of children with attentiondeficit hyperactivity disorder symptoms: a randomized, double-blind, placebo-controlled trial. Arch Gen Psychiatry 1997; 54: 857-864.

53. The MTA Cooperative Group. A 14-month randomized clinical trial of treatment strategies for attention-deficit/hyperactivity disorder. Arch Gen Psychiatry 1999; 56: 1073-1086.

54. Swanson JM, Kraemer HC, Hinshaw SP, Arnold LE, Conners CK, Abikoff HB, Clevenger W, Davies M, Elliott GR, Greenhill LL, Hechtman L, Hoza B, Jensen PS, March JS, Newcorn JH, Owens EB, Pelham WE, Schiller E, Severe JB, Simpson S, Vitiello B, Wells $\mathrm{K}$, Wigal T, Wu M. Clinical relevance of the primary findings of the MTA: success rates based on severity of ADHD and ODD symptoms at the end of treatment. J Am Acad Child 
Adolesc Psychiatry 2001; 40: 168-179.

55. Safer DJ, Krager JM. The increased rate of stimulant treatment for hyperactive/inattentive students in secondary schools. Pediatrics 1994; 94: 462-464.

56. Safer, DJ, Zito J, Fine EM. Increased methylphenidate usage for attention deficit disorder in the 1990s. Pediatrics 1996; 98: 1084-1088.

57. Robison LM, Sclar DA, Skaer TL, Galin RS. National trends in the prevalence of attentiondeficit/hyperactivity disorder and the prescribing of methylphenidate among school-age children. Clin Pediatr (Phila) 1999; 38: 209-17.

58. Zito JM, Safer DJ, dosReis S, Gardner JF, Boles M, Lynch F. Trends in the prescribing of psychotropic medications to preschoolers. JAMA 2000; 283: 1025-1030.

59. Schirm E, Tobi H, Zito JM, de Jong-van den berg LTW. Psychotropic medication in children: a study from The Netherlands. Pediatrics 2001; 108(2). www.pediatrics.org/ cgi/content/full/108/2/e25.

60. Safer DJ, Malever M. Stimulant treatment in Maryland public schools. Pediatrics 2000; 106: 533-539.

61. Valentine J, Zubrick S, Sly P. National trends in the use of stimulant medication for attention deficit hyperactivity disorder. J Paediatr Child Health 1996; 32: 223-27.

62. Jensen PS, Kettle L, Roper MT, Sloan MT, Dulcan MK, Hoven C, Bird HR, Bauermeister JJ, Payne JD. Are stimulants overprescribed? Treatment of ADHD in four US communities. J Am Acad Child Adolesc Psychiatry 1999; 38: 797-804.

63. Efron D, Jarman F, Barker M. Side effects of methylphenidate and dexamphetamine in children with attention deficit hyperactivity disorder: a double-blind, crossover trial. Pediatrics 1997; 100: 662-666.

64. Spencer T, Biederman J, Wilens T. Growth deficits in children with attention deficit hyperactivity disorder. Pediatrics 1998; 102(2) Suppl: 501-506.

65. Kramer JR, Loney J, Ponto LB, Ann Roberts M, Grossmans. Predictors of adult height and weight in boys treated with methylphenidate for childhood behavior problems. J Am Acad Child Adolesc Psychiatry 2000; 39: 517-524.

66. Gadow KD, Sverd J, Sprafkin J, Nolan E, Grossman S. Long-term methylphenidate therapy in children with comorbid attention-deficit hyperactivity disorder and chronic multiple tic disorder. Arch Gen Psychiatry 1999; 56: 330-336.

67. National Institutes of Health Consensus Development Panel. National Institutes of Health Consensus Development Conference Statement: diagnosis and treatment of attentiondeficit/hyperactivity disorder (ADHD). J Am Acad Child Adolesc Psychiatry 2000; 39: 182-193.

68. Greenhill LL, Halperin JM, Abikoff H. Stimulant medications. J Am Acad Child Adolesc Psychiatry 1999; 38: 503-512.

69. Daw J. The Ritalin debate. Monitor on Psychology 2001; 32(5).

70. Musser CJ, Ahmann PA, Theye FW, Mundt P, Broste SK, Mueller-Rizner N. Stimulant use and the potential for abuse in Wisconsin as reported by school administrators and longitudinally followed children. J Dev Behav Pediatr 1998; 19: 187-192.

71. United States General Accounting Office. Attention Disorder Drugs: Few Incidents of Diversion or Abuse Identified by Schools. Washington, DC: United States General Accounting Office, 2001.

72. NSW Department of Health. Criteria for the Diagnosis and Management of Attention Deficit Hyperactivity Disorder in Children and Adolescents. Sydney: NSW Department of Health, 1999. Publication no. TG181/4

73. NSW Department of School Education. Talk, Time, Teamwork: Collaborative Management of Students with ADHD. Sydney: NSW Department of Education, 1995.

74. Rey J M, Walter G, Hazell PL. Psychotropic drugs and preschoolers. Med J Aust 2000; 173: $172-173$.

75. Rappley MD, Mullan PB, Alvarez FJ, Eneli IU, Wang J, Gardiner JC. Diagnosis of attention-deficit/hyperactivity disorder and use of psychotropic medication in very young children. Arch Pediatr Adolesc Med 1999; 153: 1039-1045. 
76. Efron D. The prescription of psychotropic medication by Australian paediatricians and child psychiatrists. ADHD in the Third Millennium: Perspectives for Australia, Conference Proceedings. March 16-18 2001.

77. Shelton TL, Barkley RA, Crosswait C, Moorehouse M, Fletcher K, Barrett S, Jenkins L, Metevia L. Multimethod psychoeducational intervention for preschool children with disruptive behavior: two-year post-treatment follow-up. J Abnorm Child Psychol 2000; 28: 253-266.

78. Public Health Division. The Health of the People of New South Wales-Report of the Chief Health Officer 2000. Sydney: NSW Department of Health, 2000.

79. Rappaport N, Chubinsky P. The meaning of psychotropic medications for children, adolescents, and their families. J Am Acad Child Adolesc Psychiatry 2000; 39: 11981200.

80. Efron D, Jarman FC, Barker M. Child and parent perceptions of stimulant medication treatment in attention deficit hyperactivity disorder. J Paediatr Child Health 1998; 34: 288-292.

81. Thiruchelvam D, Charach A, Schachar R. Moderators and mediators of long-term adherence to stimulant treatment in children with ADHD. J Am Acad Child Adolesc Psychiatry 2001; 40: 922-928.

82. Jensen PS, Hinshaw SP, Kraemer, HC, Lenora N, Newcorn JH, Abikoff HB, March JS, Arnold LE, Cantwell DP, Conners CK, Elliott GR, Greenhill, LL, Hechtman L, Hoza B, Pelham WE, Severe JB, Swanson JM, Wells KC, Wigal T, Vitiello B. ADHD comorbidity findings from the MTA study: comparing comorbid subgroups. J Am Acad Child Adolesc Psychiatry 2001; 40: 147-158.

\section{I Useful internet resources}

NSW Department of Health

www.health.nsw.gov.au/public-health/psb/adhd

Commonwealth of Australia Department of Health and Aged Care

www.health.gov.au/hsdd/mentalhe/index.htm

National Institute of Mental Health (U.S.)

www.nimh.nih.gov/publicat/index.cfm

Australian Network for Promotion, Prevention and Early Intervention for Mental Health (AUSEINET)

http://auseinet.flinders.edu.au/index.php

Children and Adults with Attention-Deficit/Hyperactivity Disorder (CHADD; US nonprofit organisation representing and supporting children and adults with ADHD)

www.chadd.org

National Health and Medical Research Council

www.nhmrc.gov.au/index.htm

For the NHMRC report on ADHD go to:

www.health.gov.au:80/nhmrc/publications/adhd/contents.htm 